\title{
Board Long-Term Orientation, Earnings Management, Disclosure and Risk
}

\author{
Hernan Herrera-Echeverri ${ }^{1}$, Jerry Haar ${ }^{2}$, Daniel Velasquez-Gaviria ${ }^{3,4}$, Siddharth Upadhyay ${ }^{2}$
}

\author{
${ }^{1}$ School of Economics and Finance, EAFIT University \\ Carrera $49 N^{\circ} 7$ Sur - 50 Medellin, Colombia \\ E-mail.hherrer2@eafit.edu.co \\ ${ }^{2}$ College of Business, Florida International University \\ 11200 SW 8th Street, MANGO 436, Miami, Florida 33199 \\ E-mail.haarj@fiu.edu; supad007@fiu.edu
}

${ }^{3}$ Faculty of Economic and Administrative Sciences, Metropolitan Institute of Technology-ITM

Calle 54A No. 30 - 01, 050034 Medellín, Colombia Medellin, Colombia'

E-mail.danielvelasquez@itm.edu.co

Department of Quantitative Economics, Maastricht University
Tongersestraat 5, 6211LM Maastricht, The Netherlands
E-mail.d.velasquezgaviria@maastrichtuniversdity.nl

cross $^{\text {ref }}$ http://dx.doi.org/10.5755/j01.ee.31.4.24253

\begin{abstract}
Short-term thinking continues to dominate corporate decision making due to the pressure to achieve expected quarterly earnings. As such, strategic goals take a back seat to short-term performance among the prime objectives of CEOs, the board of directors and management teams. Be that as it may, shareholders and stakeholders expect corporate leaders to pay equal attention to the long-term health of the corporate enterprise. An empirical study is conduced to test how long-term oriented board of directors diminish earnings management, increase disclosure and reduce risk. The results show that a long-term board orientation decreases earnings smoothing, stock price synchronicity and downside risk. To study this relationship, we construct a panel data from 2004 to 2015 comprising of 2834 OECD country firms. We conclude that board independence, board expertise and board audit committee activity increase long-term firm orientation. We find that boards with these characteristics are prone to the implementation of executives' long-term incentives, suggesting that a long-term orientation is beneficial not only to increase firms' transparency and disclosure but also to reduce firms' downside risk. Firms with long-term orientation reveal enough information to avoid stock price synchronicity, prevent the use of earnings management to conceal real firm performance and reduce downside risk - all decreasing the chance of financial failure. The results of the study not only nullify the arguments that there is no impact of long-term orientation and long-term incentives but also bolster and enrich the stream of literature that supports these variables' impact on earnings management, stock price synchronicity and downside risk. Within the context of the international setting of the paper, we have substantiated the external validity of the results across geographies and country-wide regulations.
\end{abstract}

Keywords: Long-Term Orientation; Board Compliance; Downside Risk; Performance Disclosure, Corporate Governance.

\section{Introduction}

With relentless pressure on firms to meet quarterly earnings expectations, it is not surprising that short-term thinking dominates corporate decision-making. CEOs, their boards and management teams focus less attention on strategic goals then on short-term performance. While boards do have a responsibility to oversee performance against plans, their shareholders and stakeholders expect them to play an equally important role in ensuring that management focuses on the long-term health of their enterprises (Daum \& Speed 2015).

Corporate managers with a long-term orientation, take a linear direction for the board, and are cognizant of the goal of maximizing shareholder value. This concept has its basis in the agency theory, set forth by economists in the 1970s. It is rooted in the idea that shareholders own the corporation and demand activities that are driven by profit maximization and-increasingly-responsible behavior by the enterprise and its officers and employees.

However, according to Bower and Lynn (2017) the theory is rife with moral hazard since shareholders are not accountable as owners for the firm's activities, nor do they have officers' and directors' fiduciary responsibilities of the enterprise. Therefore, it is primarily in the financial domain where board long-term orientation may have impact on earnings management, disclosure and risk and, as such, yield implications for an enterprise's performance and equity value.

Recently, focus is shifting to board long-term orientation and its implications on earnings management, disclosure and risk. Researchers are trying to answer one major question - what is the exact impact of long-term orientation on firm performance? However, this is a very broad question and may not have a simple, straight answer.

The reason being that there is no direct relationship between these two variables, but it is, in a way combined 
effects of all the variables that change with long term orientation. Perhaps that is why there really hasn't been a true effect measured. This is what we are trying to accomplish with this paper - an understanding and measure of the impact of long-term orientation of the board of directors on major outcome variables.

Previous studies (Xie et al., 2003; Armstrong et al., 2014; Chen et al., 2015, among others) have tried to document positive association between good governance and disclosure quality, but they have missed analyzing how a long-term orientation can affect that relation. The mainstream research in this sense have focused on the effect of country-specific factors, such as investor protection, institutional factor and on information transparency. This limits the pervious literature from 1) achieving an expansive validity of the results that strengthen the evidence under discussion and 2) refuting the possibility that countryspecific corporate culture and prevalent corporate governance practices might lead to skewed results.

Thus, our work gives a new perspective considering simultaneously an international setting and a firm-level governance structure. Additionally, the international setting makes it possible to use regulation reforms across countries as an exogenous variation in board structure to have more robust results, which could not be achieved in a withincountry setting. This is particularly important because it permits enhancing our knowledge on corporate governance and disclosure practices, in-as-much the prior literature has documented mixed evidence across different countries using industry and country data. International firm level results contribute to increased generalizability of the findings for multiple countries; not only about the relation between board compliance, disclosure and risk but also to establish if the long-term orientation boosts firm transparency or not.

Based on our results of the empirical study, we conclude that board independence, board expertise and board audit committee activity increase long-term firm orientation. We find that boards with those characteristics are prone to the implementation of executives' long-term incentives, suggesting that a long-term orientation is beneficial not only to increase firms' transparency and disclosure but also to reduce firms' downside risk. Firms with long-term orientation reveal enough information to avoid stock price synchronicity, prevent the use of earnings management to conceal real firm performance and reduce downside risk-all decreasing the chance of financial failure.

The paper follows with a literature review in section 2 , examining the works from late 1990s to present research. Section 3 describes the data, section 4 the estimation model, section 5 discuss the results and section 6 present conclusions and further research opportunities.

\section{Literature Review}

Board expertise and independence brings in more transparency and increases performance disclosure (Cunningham, 2008; Jeanjean \& Stolowy, 2009, Johl Kaur, Kaur \& Cooper, 2015). Although, it has been argued that there is mixed or no influence of board independence on a firm's performance, it is also evident that independent directors provide unbiased judgement in order to represent the shareholders (Fuzi, Halim, M. K., 2016; Rashid, 2018). In this sense Alhaji and Wan Yusoff (2012) mentions, audit committee does not only ensure transparency and accuracy of financial reporting and disclosures, but it also promotes good corporate governance, which is evidenced empirically. The influence of audit committee on firm performance depend on the committee's characteristics, wherein, again, board expertise and board independence are key factors (Qinghua, Pingxin \& Junming, 2007; Kallamu \& Saat, 2015; Barka \& Legendre, 2016; Sarpal 2017; Zhou, Owusus-Ansah, Maggina, 2018).

Moreover, Karamanou and Vafaes (2005) found that in firms with more effective boards and audit committee structures, the management earnings forecasts are more accurate and up-to date and Aldamen, Duncan, Kelly, McNamara and Nagel (2012) argued that more expertise and experienced managers have a positive impact on accounting performance. With that, we move forward to prove with empirical evidence the relationship of all the above-mentioned factors involved in to establish that boards with audit committee, higher independence, expertise and compliance are more likely to reduce earnings management, increase disclosure and also more likely to adopt long-term incentives policies. Unlike other studies (Alhaji \& Wan Yusoff, 2012; Zhou, Owusus-Ansah, \& Maggina, 2018) we take a holistic approach and with a larger geographical scope, which adding to the existing research, also supplements the findings with more depth.

Hypothesis 1. Boards with (a) an audit committee, (b) higher independence, (c) expertise, (d) and compliance are more likely to reduce earnings management and increase the performance disclosure.

Additionally, the data presented by McKinsey Global Institute shows that the firms that manage for a long-term display better average company revenue, average company earnings, average economic profit and average market capitalization. The study also found a high correlation between long-term approach of firms and their superior historical performance (Barton, Manyika \& Williamson, 2017; O’Hanley 2017).

Long-term is usually defined as a period of more than 3 to 5 years and a long-term orientation board of directors instigates collaborative management defining the strategic vision for the firm over that period or more. This effect is also observed in European markets where firms with longterm serving board gained better investor confidence (Daum $\&$ Speed, 2015). It has been mentioned that factors such as board independence, and board expertise (effective, skilled and diverse board) have an important role in influencing the long-term orientation of board, as well as, improving risk mitigation and risk oversight (Ferguson, 2009; Willis et al., 2009; Leech, 2017). However, most related literature on executive compensation or long-term incentive plans such as Murphy (1999) or Buck, Bruce, Main and Udueni, (2003), has been two dimensional at best. The implication of board compliance over long-term orientation has seldom been provided, but we postulate that it is certain because better boards that induce higher investor confidence are characterized by focusing in long-term performance more than showing short term results. 
Hypothesis 2. Boards with (a) audit committee (b) higher independence, (c) expertise (d) and compliance are more likely to adopt executives' long-term incentives policies.

Finally, we test if the adoption of long-term incentive policies reduces earnings management, increase performance disclosure and reduce downside risk. Empirical evidence of relationship between executive compensation and firm performance has been strongly established through pay-performance sensitivity analysis (Murphy, 1998; Shah \& Sunder, 1999; Lopez-Iturriaga, Garcia-Meca, Tejerina-Gaite; 2014). The sensitivity of total executive rewards to share price performance is considered a measure to judge the effect of executive compensation on shareholder's interests (Buck, Bruce, Main and Udueni, 2003). It is also argued that for long-term sustainability of a firm, executives' pay should be used to promote long-term shareholder value and also for the long-term interests of the firm and its employees (Mohamed \& Salazar, 2016). Therefore, with direct influence of long-term incentive plan to the firm performance and corporate stock price, we seek to establish the effects of long-term incentives orientation by providing support and overcoming the limitations of previous literature.

Hypothesis 3. Firms with long term incentives orientation are more likely to (a) reduce earnings management, increase the performance disclosure and (b) reduce downside risk.

We would like to emphasize that we are projecting a direct relationship between long term incentive policies and downside risk. Board long term orientation is predictive variable for all three variables, that is SPS, earnings management and downside risk while at the same time acting as a mediator between board compliance, board audit committee, board independence and board expertise.

SPS and downside risk both are meant to have a negative relationship as seen in the model below and therefore, any independent relationship between those variables will be hard to observe in our model and hence, the exclusion of the same.

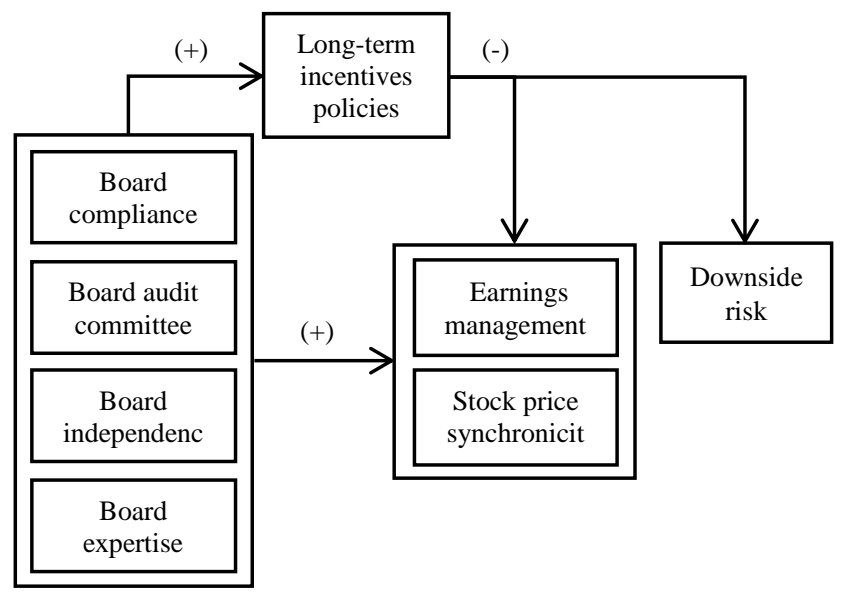

Figure 1. Relationships

\footnotetext{
${ }^{1}$ The OECD Principles and Guidelines for Access to Research Data from Public Funding document can be accessed at: http://www.oecd.org/sti/inno/38500813.pdf
}

\section{Data Description and Variables}

We obtained data of 2834 OECD country-firms from 2004 to 2015 in annual periodicity ${ }^{1}$. We include firms with information about board of directors available in the DataStream database. The financial and public sectors were excluded. The quality of firms' financial and board data was analyzed, and cross-integrity was checked in some cases with alternative sources. We used data from OECD country firms largely for two reasons: 1) The year-on-year data obtained is accurate and largely unaffected by any external factors such as economic or geo-political instability and 2) Data from 36 countries covers a wide range of governance cultures and thus, complementing the international setting. Moreover, the working methods of OECD for statistical data collection assures quality framework, facilitates metadata exchange, and uses a statistical information system for data efficiency, which provides for data integrity and robustness $^{2}$. As a matter of fact, Juan Yermo (2008) mentions how the OECD guidelines support the robustness of data gathered by addressing governance and investment issues, making OECD the perfect data source for our research.

Countries like U.S. and U.K. have more information than countries like Hungary or Slovak Republic. This fact shouldn't affect the results in-as-much our unit of analysis is the firm, but to be sure that we have reliable results, we tested the models without U.S. and U.K. and the results were similar.

\section{Independent Variables}

Board compliance: It is the average of all 27 scores in the DataStream database related with boards' observation of main corporate governance issues (Appendix B available by request to the authors). knowing that scores from DataStream have some issues with missing and erroneous data, we reviewed all data before including it in the sample and cleared up any inconsistent records. All items that pertain to compliance issues are assigned with 0 or 1 .

To perform a sensibility analysis, we study definitions of all 27 scores in the DataStream database. Based on those definitions and on verification of the specific meaning, we classify the variables in three categories - the variables related with board audit activities (items 1 to 3), related with board independence (items 20, 24 and 27), and related with board expertise (items 16 and 26). We calculate the average of each category and use those results with independent variables in some regressions; as the "ad hoc" classification to check and confirm our results.

Long term orientation: A signal of firm long-term orientation is the adoption of long-term incentive (LTI) plans for management compensation. An LTI plan is a longterm variable pay component commonly based on a multiyear vesting or lock-in period. LTI plan implementation has been increasing over the past decades in firms around the world. We know that a main responsibility of the board of directors is the design and approval of the managers' compensation strategy. We use the target year of the

\footnotetext{
${ }^{2}$ More information on OECD data collection methods can be found at: http://www.oecd.org/statistics/statisticalresources.htm
} 
compensation plan for managers reported in the DataStream database as a proxy for board long-term orientation.

Earnings management: We follow Leuz et al. (2003), Bhattacharya et al. (2003), and DeNicolo et al. (2008) and use the earnings smoothing (ES) as a proxy of earnings management. ES tracks the extent to which managers may conceal the true performance of firms using accruals to smooth fluctuations of annual profits. Unlike the authors above, who use a pooled cross section data for each country, our measures are calculated for each year and each firm in a rolling window of three years between 2012 until 2015. Accruals (AS) for firm "I" at year " $t$ " are estimated as:

$$
\begin{aligned}
A S_{i t}=\left(\Delta C A_{i t}-\right. & \left.\Delta \operatorname{Cash}_{i t}\right) \\
& -\left(\Delta C L_{i t}-\Delta S T D_{i t}-\Delta T P_{i t}\right) \\
& -d e p_{i t}
\end{aligned}
$$

Where "CA" denotes current assets, "Cash" is cash and cash equivalents, "CL" indicates the current liabilities, "STD" is short-term debt and the current portion of longterm debt, "TP" is income tax payable, and "dep" denotes depreciation and amortization. Cash flow from operations are estimated by extracting the accruals from the operative income $(\mathrm{OI})$ :

$$
E C F_{i t}=O I_{i t}-A S_{i t}
$$

The earnings smoothing is calculated by the Spearman rank order correlation between changes in accruals and changes in estimated cash flow, both normalized by one period lag of firm total assets:

Earnings Smoothing $_{\text {it }}$

$$
=1-\frac{6 \sum_{i, t}^{N}\left(\operatorname{Rank}\left(\frac{\Delta A S_{i t}}{T A_{i t-1}}\right)-\operatorname{Rank}\left(\frac{\Delta E C F_{i t}}{T A_{i t-1}}\right)\right)}{N\left(N^{2}-1\right)}
$$

The Earnings smoothing will fall in the unit interval and increase its value, as the firm is less opaque in its statements. For example, Mexico's Earnings Smoothing result is -0.64 and U. S. has -0.5. Thus, data indicates that firms in U. S. perform less earnings management than firms in Mexico on an average. Hence, we expect a positive relationship with board compliance and firm long-term orientation.

Performance disclosure: We use Stock Price Synchronicity (SPS) as an alternative measure of accounting transparency and disclosure. Morck et al. (2000) and Jin and Meyers (2006) find a positive relationship between stock price synchronicity and lack of disclosure. Yearly SPS is obtained using the regression specified below. The model is built by calculating weekly return $r_{i t}$ for each firm "i" at week "t"; secondly, we compute the returns of the local county market index and we estimate returns of the S\&P500 market and the exchange rate (EX) for each country by the equation (4) given below.

$$
\begin{aligned}
& r_{i t}=\alpha_{i}+\beta_{1, i} r_{m, j t}+\beta_{2}\left[r_{U S, t}+E X_{j t}\right]+ \\
& \beta_{3, i} r_{m, j t-1}+\beta_{4}\left[r_{U S, t-1}+E X_{j t-1}\right]+ \\
& \beta_{5, i} r_{m, j t-2}+\beta_{6}\left[r_{U S, t-2}+E X_{j t-2}\right]+ \\
& \beta_{7, i} r_{m, j t+1}+\beta_{8}\left[r_{U S, t+1}+E X_{j t+1}\right]+ \\
& +\beta_{9, i} r_{m, j t+2}+\beta_{10}\left[r_{U S, t+2}+E X_{j t+2}\right]+\epsilon_{i t}
\end{aligned}
$$

Where $r_{m, j t}$ is the local market index return for each county " $\mathrm{j}$ " during the time period " $\mathrm{t}$ ", $r_{U S, t}$ is the S\&P500 market index return, and $E X_{j t}$ is the exchange rate in country “ $\mathrm{j}$ ". We run the model and obtain the coefficient of determination $\left(\mathrm{R}^{2}\right)$ for each firm by year. Then, $S P S_{i, T}=$ $R_{i, t}^{2}$, where $\mathrm{T}$ refers to years.

Risk: We use downside risk as a measure of firm risk (Huang et al., 2012; Ang et al., 2006). Downside risk is an estimation of a stock's potential to experience a drop-in value when the market conditions change. To calculate the downside risk variable, we downloaded the prices of 2810 shares $\left(P_{\text {iwkt }}\right)$ from DataStream and its country stock exchange index reference benchmark $\left(B_{w k t}\right)$ on a weekly basis, where i represents the firm, w represents the 52 weeks of a year, $t$ the number of years from 2004 to 2015 and $\mathrm{k}$ represents the country. Then we build weekly log returns for stock prices and benchmarks in equation (5) and (6).

$$
\begin{aligned}
& r_{i w t k}=\ln \left(\frac{P_{i w k t}}{P_{i w k t-1}}\right) \\
& r b_{w t k}=\ln \left(\frac{B_{w k t}}{B_{w k t-1}}\right)
\end{aligned}
$$

Where $r_{i w k t}$ represents the log return of the firm i, on the week $\mathrm{w}$, on the year $\mathrm{t}$ for the country $\mathrm{k}$. On the other hand, $r b_{w k t}$ represents the log return of the stock index benchmark in country $\mathrm{k}$, on the week $\mathrm{w}$, on the year $\mathrm{t}$. Thereafter, with the weekly returns of each share and the country benchmarks, we construct the annual semi standard deviation for each one shown in equations (7) and (8).

$$
\begin{gathered}
\sigma_{i k t}=\sqrt{\frac{\sum_{h=1}^{H}\left(r_{i w k t}-\bar{r}_{i k t}\right)}{H}} \\
\sigma b_{k t}=\sqrt{\frac{\sum_{m=1}^{M}\left(r_{w k t}-\bar{r}_{k t}\right)}{H}}
\end{gathered}
$$

Where $H=\sum 1_{\left\{r_{i w k t}<\bar{r}_{i k t}\right\}}$, and $M=\sum 1_{\left\{r_{w k t}<\bar{r}_{k t}\right\}}$, also $\sigma_{i k t}$ is the standard semi-standard deviation for the firm $\mathrm{i}$, on year $\mathrm{t}$, for country k. $\sigma b_{k t}$ is the semi-standard deviation for country $k$, on year $t$. Therefore, the annual down side risk is:

$$
d s r_{i k t}=\frac{\sigma_{i k t}}{\sigma b_{k t}}
$$

\section{Control Variables}

Four control variables are included to ensure the validity of the relation between the explanatory variables and dependent variables. Firsts, total assets and market capitalization to control any firm size specific, timeinvariant effects on transparency, disclosure and risk (Jiambalvo et al., 2002; Klein, 2002; Chen et al., 2001 and Hutton et al., 2009). Second, financial leverage, which equals the book value of total financial debt to control firm indebtedness level. (Park and Shin, 2004, Xu et al., 2004 and Yuan et al., 2016). Third, Global Competitive Index (GCI) to control country specific developments that vary over time. We expect that higher GCI is a result of continuous stable macroeconomic conditions in the country. Firms in stable environments adopt long-term development strategies and will show high disclosure, less earnings management practices and fewer extreme downside risk incidents. We formally test this hypothesis and find, as expected, that GCI is positively and significantly correlated with less earnings management, low stock price synchronicity and less downside risk. Nevertheless, longterm incentive policies survive as a both economically and statistically significant determinant of earnings management, stock price synchronicity and downside risk. 
Finally, we include control of industry-year fixed effects to account for any unobservable trends at the year and sector level. Appendix A, available by request to the authors, depicts variables used, their description and sources. Table 1 shows summary statistics for the sample, assets, debt and market capitalization in millions and Table 2 presents descriptive statistics by country. Similarly, Table 3 shows mean and standard deviation of each variable from 2004 to 2015.

Table 1

Summary Statistics I

\begin{tabular}{|l|c|c|c|}
\hline \multicolumn{1}{|c|}{ Variable } & Observations & Mean & $\begin{array}{c}\text { Standard } \\
\text { Deviation }\end{array}$ \\
\hline Earning Smoothing & 30752 & -0.54 & 0.49 \\
\hline Stock Price Synchronicity & 22364 & 0.32 & 0.16 \\
\hline Down Side Risk & 31360 & 1.85 & 1.09 \\
\hline Board Compliance & 23973 & 0.46 & 0.17 \\
\hline Board Independence & 23973 & 0.52 & 0.17 \\
\hline Board Expertise & 23973 & 0.49 & 0.20 \\
\hline Board Audit & 23973 & 0.54 & 0.19 \\
\hline Long Term Incentives & 15440 & 3.29 & 1.19 \\
\hline Global Competitive Index & 34008 & 5.35 & 0.32 \\
\hline Assets & 32975 & 709.23 & 5561.1 \\
\hline Debt & 32935 & 211.15 & 1693.8 \\
\hline Market Capitalization & 32137 & 947 & 24.812 \\
\hline
\end{tabular}

Table 2

Summary Statistics II. A.

\begin{tabular}{|l|c|c|c|c|c|}
\hline \multicolumn{1}{|c|}{ Average } & $\mathbf{2 0 0 5}$ & $\mathbf{2 0 0 6}$ & $\mathbf{2 0 0 7}$ & $\mathbf{2 0 0 8}$ & $\mathbf{2 0 0 9}$ \\
\hline Stock Price Synchronicity & 0.158 & 0.288 & 0.337 & 0.363 & 0.403 \\
\hline Earning Smoothing & -0.567 & -0.522 & -0.518 & -0.556 & -0.576 \\
\hline Board compliance & 0.436 & 0.425 & 0.437 & 0.436 & 0.453 \\
\hline Board Independence & 0.496 & 0.492 & 0.492 & 0.504 & 0.517 \\
\hline Board Expertise & 0.427 & 0.423 & 0.421 & 0.438 & 0.469 \\
\hline Board Audit & 0.510 & 0.503 & 0.506 & 0.520 & 0.538 \\
\hline Long Term Incentives & 3.458 & 3.313 & 3.312 & 3.336 & 3.346 \\
\hline Total Assets & 4.582 & 4.845 & 5.224 & 5.757 & 6.886 \\
\hline Total Debt & 1.449 & 1.443 & 1.484 & 1.613 & 2.155 \\
\hline Market Cap & 0.158 & 0.288 & 0.337 & 0.363 & 0.403 \\
\hline
\end{tabular}

Table 3

Summary Statistics II. B.

\begin{tabular}{|l|c|c|c|c|c|c|}
\hline \multicolumn{1}{|c|}{ Average } & $\mathbf{2 0 1 0}$ & $\mathbf{2 0 1 1}$ & $\mathbf{2 0 1 2}$ & $\mathbf{2 0 1 3}$ & $\mathbf{2 0 1 4}$ & $\mathbf{2 0 1 5}$ \\
\hline Stock Price Synchronicity & 0.370 & 0.363 & 0.396 & 0.292 & 0.296 & 0.345 \\
\hline Earning Smoothing & -0.527 & -0.523 & -0.527 & -0.563 & -0.573 & -0.569 \\
\hline Board compliance & 0.459 & 0.464 & 0.463 & 0.468 & 0.462 & 0.461 \\
\hline Board Independence & 0.521 & 0.528 & 0.535 & 0.536 & 0.534 & 0.533 \\
\hline Board Expertise & 0.494 & 0.508 & 0.505 & 0.506 & 0.509 & 0.507 \\
\hline Board Audit & 0.544 & 0.544 & 0.548 & 0.548 & 0.549 & 0.550 \\
\hline Long Term Incentives & 3.247 & 3.445 & 3.367 & 3.327 & 3.204 & 3.197 \\
\hline Total Assets & 7.002 & 7.358 & 7.281 & 7.668 & 8.708 & 9.303 \\
\hline Total Debt & 2.207 & 2.224 & 2.206 & 2.324 & 2.578 & 2.694 \\
\hline Market Cap & 0.370 & 0.363 & 0.396 & 0.292 & 0.296 & 0.345 \\
\hline
\end{tabular}

\section{Estimation}

In all cases we use panel data models, where the main unit of observation is the board variables in a firm-year. $X_{i t}$ and $Z_{i t}$ indicate the associated variables to board and control variables respectively to each firm in a year. $D_{i}$ is a matrix of year dummies to control time effects, which is common to all firms. $D_{j}$ is a matrix of dummies to control country effects. $\varepsilon_{i t}$ is the idiosyncratic error.

To measure how board compliance, independence, expertise and audit committee activity influence earnings management, disclosure and risk we use equation (10) where $Y_{i t}$ denotes the earning smoothing, stock price synchronicity and downside risk variables

$$
\begin{aligned}
Y_{i t}=\beta_{0}+\beta_{1} X_{i t} & +\beta_{2} Z_{i t}+\beta_{3} D_{i}+\beta_{4} D_{j} \\
& +\varepsilon_{i t}
\end{aligned}
$$

To test the relationship between board compliance, independence, expertise and audit committee with managers' long-term incentives adoption we use equation (11) where $C_{i t}$ is the target year for the compensation plan for managers in a firm-year:

$$
\begin{aligned}
C_{i t}=\beta_{0}+\beta_{1} X_{i t} & +\beta_{2} Z_{i t}+\beta_{3} D_{i}+\beta_{4} D_{j} \\
& +\varepsilon_{i t}
\end{aligned}
$$

Finally, we test the effects of the adoption of managers' long-term incentives over earnings management, disclosure and risk with the model described in equation (12):

$$
\begin{aligned}
Y_{i t}=\beta_{0}+\beta_{1} C_{i t} & +\beta_{2} Z_{i t}+\beta_{3} D_{i}+\beta_{4} D_{j} \\
& +\varepsilon_{i t}
\end{aligned}
$$

\section{Results, Analysis and Discussion}

\section{Board Compliance, Earnings Management and Disclosure}

Table 4, column (1) presents the estimates from panel data regression of board compliance variables and from earnings smoothing. The main explanatory variable is firmyear board compliance. The coefficient is significantly positive, implying that earnings smoothing is higher in firms with higher board compliance. In columns (2), (3), (4) explanatory variables are board independence, board expertise and audit committee activity; again, the coefficients are significantly positive in all cases. Because higher earnings smoothing indicate less earnings opacity, we can conclude that boards with audit committee, higher independence, expertise and in general high compliance are more likely to reduce earnings management. Board

\begin{tabular}{|c|c|c|c|c|}
\hline \multicolumn{5}{|c|}{ Dependent Variable: Earning Smoothing } \\
\hline \multicolumn{5}{|c|}{$\begin{array}{l}\text { Panel data estimation } \\
\end{array}$} \\
\hline Variable & 1 & 2 & 3 & 4 \\
\hline Board Compliance & $\begin{array}{c}0.1195^{* * * *} \\
(0.0197)\end{array}$ & & & \\
\hline $\begin{array}{l}\text { Board } \\
\text { Independence }\end{array}$ & & $\begin{array}{c}0.1526 \text { **** } \\
(0.0198) \\
\end{array}$ & & \\
\hline Board Expertise & & & $\begin{array}{c}0.2144 * * * \\
(0.0171) \\
\end{array}$ & \\
\hline Board Audit & & & & $\begin{array}{c}0.1969 * * * * \\
(0.0178)\end{array}$ \\
\hline Assets & & & & \\
\hline Debt & & & & \\
\hline $\begin{array}{l}\text { Global } \\
\text { Competitive Index }\end{array}$ & & & & \\
\hline Constant & $\begin{array}{c}-0.600 * * * * \\
(0.0096)\end{array}$ & $\begin{array}{c}0.625 * * * \\
(0.0109)\end{array}$ & $\begin{array}{c}-0.649 * * * * \\
(0.0089)\end{array}$ & $\begin{array}{c}-0.651 \text { *** } \\
(0.0102)\end{array}$ \\
\hline Year fixed effects & \multicolumn{4}{|c|}{ YES } \\
\hline $\begin{array}{lr}\begin{array}{l}\text { Country } \\
\text { effects }\end{array} & \text { fixed } \\
\end{array}$ & \multicolumn{4}{|c|}{ YES } \\
\hline Wald Chi Squared & 36.7433 & 59.5501 & 158.1163 & 122.5337 \\
\hline Observations & 20948 & 20948 & 20948 & 20948 \\
\hline
\end{tabular}
expertise demonstrates a higher coefficient; and one could infer that this variable has a greater impact on earnings management reduction (Hypothesis 1).

Table 4

Earnings Smoothing and Board Compliance 
Hernan Herrera-Echeverri, Jerry Haar, Daniel Velasquez-Gaviria, Siddharth Upadhyay. Board Long-Term Orientation, ...

Table 5

Earnings Smoothing and Board Compliance

\begin{tabular}{|l|c|c|c|c|}
\hline \multicolumn{5}{|c|}{ Dependent Variable: Earning Smoothing } \\
\hline Variable & 5 & 6 & 7 & 8 \\
\hline Board Compliance & $\begin{array}{c}0.0961^{* * *} \\
(0.0199)\end{array}$ & & & \\
\hline Board & & $0.1317^{* * *}$ & & \\
Independence & & $(0.0201)$ & & \\
\hline Board Expertise & & & $0.1925^{* * *}$ & \\
\hline Board Audit & & & & $0.1755^{* * *}$ \\
& & & $0.0181)$ \\
\hline Assets & $0.0022^{* *}$ & $0.0023^{* *}$ & $0.0023^{* *}$ & $0.0021^{* *}$ \\
& $(0.0010)$ & $(0.0010)$ & $(0.0010)$ & $(0.0010)$ \\
\hline Debt & $-0.012^{* * *}$ & $-0.012^{* * *}$ & $-0.011^{* * *}$ & $-0.012^{* * *}$ \\
$(0.0034)$ & $(0.0034)$ & $(0.0034)$ \\
\hline Global & $0.0906^{* * *}$ & $0.0874^{* * *}$ & $0.0658^{* * *}$ & $0.0784^{* * *}$ \\
Competitive Index & $(0.0121)$ & $(0.0121)$ & $(0.0123)$ & $(0.0121)$ \\
\hline Constant & $-1.042^{* * *}$ & $-1.050^{* * *}$ & $-0.957^{* * *}$ & $-1.028^{* * *}$ \\
& $(0.0644)$ & $(0.0644)$ & $(0.0647)$ & $(0.0643)$ \\
\hline Year fixed effects & \multicolumn{5}{|c|}{ YES } \\
\hline Country fixed & \multicolumn{5}{|c|}{ YES } \\
effects & 166.2447 & 186.2229 & 260.6873 & 237.7474 \\
\hline Wald Chi Squared & 20928 & 20928 & 20928 & 20928 \\
\hline Observations & &
\end{tabular}

In columns (5) to (8) we test the robustness of the above results, including control variables. In our sample, larger firms and firms in more competitive countries are less likely to be exposed to earning management. We found a negative relationship between level of debt and earnings smoothing.

Table 5 presents an additional way to check the above results. Column (1) presents the estimates from the panel data regressions of board compliance variables on stock price synchronicity. The main explanatory variable is board compliance in a particular firm in each year. The coefficient is negative and significant. Stock price synchronicity is lower in firms with higher board compliance. In columns (2), (3), (4) explanatory variables are board independence, board expertise and audit committee; again, the coefficients are negative and significant in all cases. As lower stock price synchronicity indicates higher performance disclosure, we can argue that boards with audit committee, higher independence, expertise and in general higher compliance are more likely to increase disclosure, confirming Hypothesis 1 integrally. In this case, the board audit committee variable displays a higher coefficient; and we could infer that this variable has a greater impact on the quality of a firm's information availability.

With these results, we put to rest the argument that there might be a mixed or no influence of board independence brings on transparency and performance. Higher the board independence, better the unbiased judgement in representing the shareholders (Fuzi, Halim, M.K., 2016; Rashid, 2018).

Table 6

Stock Price Synchronicity and Board Compliance

\begin{tabular}{|l|c|c|c|c|}
\hline \multicolumn{5}{|c|}{ Dependent Variable: Stock Price Synchronicity } \\
\hline Panel data estimation \\
\hline Variable & $\mathbf{1}$ & $\mathbf{2}$ & $\mathbf{3}$ & $\mathbf{4}$ \\
\hline Board & $-0.2014^{* * *} *$ & & & \\
Compliance & $(0.0070)$ & & & \\
\hline Board & & $-0.2508^{* * *}$ & & \\
Independence & & $(0.0067)$ & & \\
\hline
\end{tabular}

\begin{tabular}{|l|c|c|c|c|}
\hline \multicolumn{5}{|c|}{ Dependent Variable: Stock Price Synchronicity } \\
\hline $\begin{array}{l}\text { Board } \\
\text { Expertise }\end{array}$ & & & $\begin{array}{c}-0.2311^{* * * *} \\
(0.0059)\end{array}$ & \\
\hline Board Audit & & & & $\begin{array}{c}-0.2975^{* * *} \\
(0.0058)\end{array}$ \\
\hline $\begin{array}{l}\text { Market } \\
\text { capitalization }\end{array}$ & & & & \\
\hline Debt & & & & \\
\hline $\begin{array}{l}\text { Global } \\
\text { Competitive } \\
\text { Index }\end{array}$ & & & & \\
\hline Constant & $0.4378^{* * *}$ & $0.4762^{* * *}$ & $0.4560^{* * *}$ & $0.5033^{* * *}$ \\
$(0.0034)$ & $(0.0036)$ & $(0.0030)$ & $(0.0033)$ \\
\hline $\begin{array}{l}\text { Year fixed } \\
\text { effects }\end{array}$ & & \multicolumn{3}{|c|}{ YES } \\
\hline $\begin{array}{l}\text { Country fixed } \\
\text { effects }\end{array}$ & & \multicolumn{3}{|c|}{ YES } \\
\hline $\begin{array}{l}\text { Wald Chi } \\
\text { Squared }\end{array}$ & 833.09 & 1420.96 & 1551.47 & 2610.42 \\
\hline Observations & 15228 & 15228 & 15228 & 15228 \\
\hline
\end{tabular}

Table 7

Stock Price Synchronicity and Board Compliance

\begin{tabular}{|c|c|c|c|c|}
\hline \multicolumn{5}{|c|}{ Dependent Variable: Stock Price Synchronicity } \\
\hline \multicolumn{5}{|c|}{ Panel data estimation } \\
\hline Variable & 5 & 6 & 7 & 8 \\
\hline $\begin{array}{l}\text { Board } \\
\text { Compliance }\end{array}$ & $\begin{array}{c}-0.1564 * * * \\
(0.0064)\end{array}$ & & & \\
\hline $\begin{array}{l}\text { Board } \\
\text { Independence }\end{array}$ & & $\begin{array}{c}-0.199 \text { **** } \\
(0.0062) \\
\end{array}$ & & \\
\hline $\begin{array}{l}\text { Board } \\
\text { Expertise }\end{array}$ & & & $\begin{array}{c}-0.166 * * * * \\
(0.0056) \\
\end{array}$ & \\
\hline Board Audit & & & & $\begin{array}{c}-0.255^{* * * *} \\
(0.0054)\end{array}$ \\
\hline $\begin{array}{l}\text { Market } \\
\text { capitalization }\end{array}$ & $\begin{array}{c}-0.3515 * * * * \\
(0.0351) \\
\end{array}$ & $\begin{array}{c}-0.322 * * * * \\
(0.0346) \\
\end{array}$ & $\begin{array}{c}-0.341 * * * * \\
(0.0348) \\
\end{array}$ & $\begin{array}{c}-0.229 * * * \\
(0.0335) \\
\end{array}$ \\
\hline Debt & $\begin{array}{c}0.0030 * * * \\
(0.0006)\end{array}$ & $\begin{array}{c}0.002 * * * \\
(0.0006)\end{array}$ & $\begin{array}{c}0.0024 * * * \\
(0.0006)\end{array}$ & $\begin{array}{c}0.002 * * * \\
(0.0006)\end{array}$ \\
\hline $\begin{array}{l}\text { Global } \\
\text { Competitive } \\
\text { Index }\end{array}$ & $\begin{array}{c}-0.1278 * * * \\
(0.0037)\end{array}$ & $\begin{array}{c}-0.124 * * * \\
(0.0037)\end{array}$ & $\begin{array}{c}-0.116^{* * * *} \\
(0.0037)\end{array}$ & $\begin{array}{c}-0.117 \text { **** } \\
(0.0035)\end{array}$ \\
\hline Constant & $\begin{array}{c}1.1273 * * * \\
(0.0197)\end{array}$ & $\begin{array}{c}1.1362 * * * \\
(0.0194) \\
\end{array}$ & $\begin{array}{l}1.068^{* * * *} \\
(0.0196)\end{array}$ & $\begin{array}{c}1.1304^{* * *} \\
(0.0188) \\
\end{array}$ \\
\hline $\begin{array}{ll}\text { Year } & \text { fixed } \\
\text { effects } & \\
\end{array}$ & \multicolumn{4}{|c|}{ YES } \\
\hline $\begin{array}{ll}\begin{array}{l}\text { Country } \\
\text { effects }\end{array} \\
\end{array}$ & \multicolumn{4}{|c|}{ YES } \\
\hline $\begin{array}{ll}\text { Wald } & \text { Chi } \\
\text { Squared } & \\
\end{array}$ & 4270.80 & 4815.05 & 4615.90 & 6257.70 \\
\hline Observations & 15179 & 15179 & 15179 & 15179 \\
\hline
\end{tabular}

As in the previous case, we test robustness in columns (5) to (8) including control variables at the firm and country levels. In our sample, larger firms and firms in more competitive countries show less stock price synchronicity. Similar to the relation found with earnings smoothing, again we found a negative relationship between level of debt and disclosure using stock price synchronicity.

\section{Board Compliance and Executives' Long-Term Incentives Policies.}

Next, in table 6, we address the second Hypothesis. Long-term incentives show a positive association with board compliance (model 1), board independence (model 2), board expertise (model 3) and board audit committee (model 4). In all cases beta associated is positive and significant at the $1 \%$ level. This means that the target year 
of the compensation plan is higher among firms with boards with characteristics mentioned above. Therefore, the joint analysis of the four board variables suggests high quality boards are able to encourage long-term incentives policy adoption, supporting Hypothesis 2.

Our findings are consistent with Ferguson (2009), Willis et al. (2009) and Leech (2017), cementing the idea that board independence, and board expertise (effective, skilled and diverse board) impact the long-term orientation of board, as well as, improving risk mitigation and risk oversight. Addtionally, we show that these variables are not two dimensional as Murphy (1999) or Buck, Bruce, Main and Udueni, (2003) presented. It would be a grave error to consider that the relationship between the said variables and our outcome variables is linear.

Table 8

Long Term Incentives and Board Compliance

\begin{tabular}{|c|c|c|c|c|}
\hline \multicolumn{5}{|c|}{ Dependent Variable: Long term Incentives } \\
\hline \multicolumn{5}{|c|}{ Panel data estimation } \\
\hline Variable & 1 & 2 & 3 & 4 \\
\hline $\begin{array}{l}\text { Board } \\
\text { Compliance }\end{array}$ & $\begin{array}{c}1.087 * * * \\
(0.059)\end{array}$ & & & \\
\hline $\begin{array}{l}\text { Board } \\
\text { Independence }\end{array}$ & & $\begin{array}{l}2.09^{* * * *} \\
(0.072)\end{array}$ & & \\
\hline $\begin{array}{l}\text { Board } \\
\text { Expertise }\end{array}$ & & & $\begin{array}{l}1.49 * * * \\
(0.055) \\
\end{array}$ & \\
\hline Board Audit & & & & $\begin{array}{l}2.57^{* * * *} \\
(0.065)\end{array}$ \\
\hline $\begin{array}{l}\text { Global } \\
\text { Competitive } \\
\text { Index }\end{array}$ & & & & \\
\hline Assets & & & & \\
\hline Debt & & & & \\
\hline Constant & $\begin{array}{l}2.65^{* * * *} \\
(0.039) \\
\end{array}$ & $\begin{array}{l}2.01 * * * * \\
(0.048)\end{array}$ & $\begin{array}{l}2.39 * * * * \\
(0.039) \\
\end{array}$ & $\begin{array}{l}1.69 * * * \\
(0.045)\end{array}$ \\
\hline $\begin{array}{lr}\text { Year } & \text { fixed } \\
\text { effects } & \end{array}$ & \multicolumn{4}{|c|}{ YES } \\
\hline $\begin{array}{l}\text { Country fixed } \\
\text { effects }\end{array}$ & \multicolumn{4}{|c|}{ YES } \\
\hline $\begin{array}{ll}\text { Wald } & \text { Chi } \\
\text { Squared } & \end{array}$ & 408.76 & 917.78 & 813.02 & 1650.21 \\
\hline Observations & 14295 & 14295 & 14295 & 14295 \\
\hline
\end{tabular}

Table 9

Long Term Incentives and Board Compliance

\begin{tabular}{|c|c|c|c|c|}
\hline \multicolumn{5}{|c|}{ Dependent Variable: Long term Incentives } \\
\hline \multicolumn{5}{|c|}{$\begin{array}{l}\text { Panel data estimation } \\
\end{array}$} \\
\hline Variable & 5 & 6 & 7 & 8 \\
\hline $\begin{array}{l}\text { Board } \\
\text { Compliance }\end{array}$ & $\begin{array}{l}0.95^{* * * *} \\
(0.059)\end{array}$ & & & \\
\hline $\begin{array}{l}\text { Board } \\
\text { Independence }\end{array}$ & & $\begin{array}{l}1.87 * * * \\
(0.073)\end{array}$ & & \\
\hline $\begin{array}{l}\text { Board } \\
\text { Expertise }\end{array}$ & & & $\begin{array}{l}1.31 * * * \\
(0.056) \\
\end{array}$ & \\
\hline Board Audit & & & & $\begin{array}{l}2.38^{* * * *} \\
(0.066)\end{array}$ \\
\hline $\begin{array}{l}\text { Global } \\
\text { Competitive } \\
\text { Index }\end{array}$ & $\begin{array}{c}0.56 * * * \\
(0.039)\end{array}$ & $\begin{array}{c}0.48 * * * \\
(0.039)\end{array}$ & $\begin{array}{c}0.41 * * * \\
(0.040)\end{array}$ & $\begin{array}{l}0.33^{* * * *} \\
(0.038)\end{array}$ \\
\hline Assets & $\begin{array}{c}0.014 * * * \\
(0.003)\end{array}$ & $\begin{array}{c}0.013 * * * \\
(0.003)\end{array}$ & $\begin{array}{c}0.015 * * * \\
(0.003)\end{array}$ & $\begin{array}{c}0.009 * * * \\
(0.002) \\
\end{array}$ \\
\hline Debt & $\begin{array}{c}-0.24 * * * \\
(0.023) \\
\end{array}$ & $\begin{array}{c}-0.19 * * * \\
(0.023)\end{array}$ & $\begin{array}{c}-0.23 * * * \\
(0.023) \\
\end{array}$ & $\begin{array}{c}-0.19 * * * * \\
(0.022) \\
\end{array}$ \\
\hline Constant & $\begin{array}{c}-0.27 \\
(0.215) \\
\end{array}$ & $\begin{array}{l}-0.46 \\
(0.212) \\
\end{array}$ & $\begin{array}{c}0.3 \\
(0.136) \\
\end{array}$ & $\begin{array}{c}-0.019 \text { **** } \\
(0.207) \\
\end{array}$ \\
\hline $\begin{array}{ll}\text { Year } & \text { fixed } \\
\text { effects } & \\
\end{array}$ & & & & \\
\hline
\end{tabular}

\begin{tabular}{|l|c|c|c|c|}
\hline \multicolumn{5}{|c|}{ Dependent Variable: Long term Incentives } \\
\hline \multicolumn{5}{|c|}{ Panel data estimation } \\
\hline $\begin{array}{l}\text { Country fixed } \\
\text { effects }\end{array}$ & \multicolumn{5}{|c|}{ YES } \\
\hline $\begin{array}{l}\text { Wald Chi } \\
\text { Squared }\end{array}$ & 773.7 & 1188.54 & 1068 & 1853.63 \\
\hline Observations & 14295 & 14295 & 14295 & 14295 \\
\hline
\end{tabular}

We test robustness of the above results in table 6 , columns (5) through (8) including control variables at firm and country level. Control variables manifest the same behavior as in preceding cases. Larger firms and firms in more competitive countries show more propensity to have a longer target year to the compensation plan. Similar to the relationship found with earning smoothing and stock price synchronicity, again identified a negative relation between level of debt and long-term incentives policy.

The literature on the relationship between firms' board performance and governance policy adoption suggests that board structure and disclosure and long-term incentive policy adoption could be jointly determined (Love, 2011; Hermalin \& Weisbach, 2003: Hermalin \& Weisbach, 1998). If firms' long-term incentives policy and transparency are endogenously related to board compliance, the estimated effect will be biased. The reversal causality is probable because firms with long-term orientation manage earnings less, disclose more, and thereby reduce the associated risks. For example, firms with institutional investors could demand more long-term orientation board of directors who reinforce governance and monitoring, which in turn reduces managers' incentives to manipulate earnings numbers and increases their incentives to disclose more, resulting in the lower firm risks. And long-term orientation board of directors can be endogenously matched with such firms.

Credible identification of the effect of firms' board compliance on long-term incentives policy adoption and earnings opacity, therefore, requires an instrument that produces exogenous variation in board compliance, but that has no direct effect on long-term incentives policy or transparency. Our objective is to test whether a firm's board compliance has a positive effect on the adoption of a longer target year for the compensation plan for managers and higher disclosure.

Table 10

Long Term Incentives and Board Compliance Endogeneity Control

\begin{tabular}{|c|c|c|c|}
\hline \multicolumn{4}{|c|}{ Dependent Variable } \\
\hline Variable & $\begin{array}{c}\text { Change in } \\
\text { Board } \\
\text { compliance } \\
\text { Improvement } \\
\text { estimated }\end{array}$ & $\begin{array}{c}\text { Stock Price } \\
\text { Synchronicity } \\
\text { variation }\end{array}$ & $\begin{array}{c}\text { Long } \\
\text { Term } \\
\text { variation }\end{array}$ \\
\hline $\begin{array}{c}\text { Change in Board } \\
\text { Compliance Rule }\end{array}$ & $\begin{array}{c}1.0463^{* * *} \\
(0.0039)\end{array}$ & $(2)$ & $(3)$ \\
\hline $\begin{array}{c}\text { Change in Board } \\
\text { Compliance } \\
\text { Estimated }\end{array}$ & & $-0.0397^{*}$ & $0.47^{* *}$ \\
\hline Global & $\begin{array}{c}0,0018 \\
(0.0026)\end{array}$ & $\begin{array}{c}-0,0215^{*} \\
(0.0129)\end{array}$ \\
\hline Competitive Index & $\begin{array}{c}-0.2152 \\
(0.1950)\end{array}$ \\
\hline Log Assets & $\begin{array}{c}0,0012^{*} \\
(0.0007)\end{array}$ & \\
\hline Log Debt & $\begin{array}{c}-0.0080 \\
(0.0006)\end{array}$ & \\
\hline Log Market Cap & 0.0008 & & \\
\hline
\end{tabular}




\begin{tabular}{|c|c|c|c|}
\hline \multirow{4}{*}{ Variable } & $\begin{array}{c}\text { Change in } \\
\text { Board } \\
\text { compliance } \\
\text { Improvement } \\
\text { estimated }\end{array}$ & $\begin{array}{c}\text { Stock Price } \\
\text { Synchronicity } \\
\text { variation }\end{array}$ & $\begin{array}{c}\text { Long } \\
\text { Term } \\
\text { variation }\end{array}$ \\
\hline & $(0.0008)$ & & \\
\hline Var Assets & & $\begin{array}{c}0.0000835^{* * *} \\
(0.0000264)\end{array}$ & $\begin{array}{c}0.0026 \\
(0.0021)\end{array}$ \\
\hline Var Debt & & $-0.0001^{*}$ & -0.0033 \\
$(0.00006)$ & $(0.0053)$ \\
\hline Var Market Cap & & $-0.0007^{*}$ & -0.000357 \\
$(0.0004)$ & $(0.000244)$ \\
\hline Constant & $-0.03106^{* *}$ & $0,5647^{* * *}$ & $3.4688^{* * *}$ \\
$(0.013)$ & $(0.063)$ \\
\hline R-Squared & $(0.0142)$ & 0,11 & 0.03 \\
\hline Observations & 9.19 & 695 & 344 \\
\hline
\end{tabular}

Similar to Duchin et al. (2010), we use recent regulations that impose changes to board structure as a source of exogenous variation in board structure. Specifically, we use country regulations that require listed firms to increase the compliance level on their boards. Appendix $\mathrm{C}$, available by request to the authors, details regulations issued for each country with the directive to increase board compliance standards under the rule "complain or explain". We explore each regulation and measure the compliance levels before and after the promulgation of the new law, and we check to see if regulations produce variations in board compliance.

We detect in our sample firms that had to increase their board compliance and other firms for which no change was required due to the issuance of new regulations. Consequently, we build a variable that capture this variation produced by new regulations (Board Compliance Rule). This variable is zero if the firm previously complied with the rules required by the new law in each country, and the variation in the level of compliance if the firm later to regulation starts the compliance and previously not complied with the rules required by the new law. Board Compliance Rule was used to predict the percentage change in independent directors due to changes in regulations in the variable Change in Board Compliance Estimated.

Inasmuch that regulations are not determined internally in the company and they don't mention explicitly mandatory rules related with increases on the measures. Thus, the firm long-term orientation and Change in Board Compliance Estimated remain exogenous because it is calculated by an external causal fact that affect board characteristics but not firm long-term orientation and disclosure. Another endogeneity concern arises because some CEOs serve as a member of board of directors but the legislation forces them to declare themselves handicapped when the board of directors is taking decisions about the remuneration policies for managers. Change in Board Compliance Estimated is a valid instrument to determinate first, the effect of a firm's board compliance on disclosure measured with Stock Price Synchronicity or Earning Smoothing and second, the effect of a firm's board compliance on long-term Orientation measure by variations on the target year of the compensation

\footnotetext{
We use stock price synchronicity as a proxy for transparency and disclosure. Results using earning smoothing were similar.

${ }^{4}$ For example see the comments made by Ronald O'Hanley during his speech on March 20, 2017 at Harvard Law School Forum on Corporate Governance and Financial Regulation: "Long-Term Value Starts at the
}

plan for managers. The above-mentioned procedure was completed regressing change in firms' long-term incentives as an independent variable and board compliance estimated as an instrument and control for contemporaneous changes in country and firm control variables. Table 6 columns 1, 2 and 3 show the results about the relation of board compliance on transparency ${ }^{3}$ and long-term incentives variation before controlling for endogeneity issues. Our results are confirmed, and they are in line with several practitioner approach ${ }^{4}$.

\section{Earnings Smoothing, Stock Price Synchronicity, Downside Risk and Long-Term Incentives}

In Table 8, we begin testing the relation between earnings smoothing and long-term incentives implementation policy. Coefficient in model 1 is significantly positive, implying that earnings smoothing is higher in firms with longer-term incentives policies. For robustness check we use models 2 and 3. In model 2, we introduce a main explanatory variable "long-term persistence". This variable indicates whether the firm has been keeping a policy to preserve the long term policy compensation for managers at least for the last 2 years. The estimate coefficient remains positive but increases its magnitude and significance to $1 \%$. In model 3 , we test the moderating effect of the presence of long-term incentives on the relation between board compliance and earning management. We include two new independent variables-"board compliance*short-term" and "board compliance*long-term" --representing the interaction between board compliance for firms whose target year to the compensation plan for managers is 2 years or less and 3 or greater respectively. Both interaction variables show a positive and significant effect; however, "board compliance*long-term" shows a higher coefficient indicating greater impact of board compliance over earnings management when a policy of long-term incentives is established, all above supports Hypothesis $3 \mathrm{a}$.

An additional robustness tests are in columns 4, 5 and 6 using the dependent variable "stock price synchronicity". In model 4, the main independent variable coefficient is significantly negative, implying that "stock price synchronicity" is lower in firms that adopt longer-term incentives policies. Columns 5 and 6 confirm results obtained in model 4. Firms that have persisted in keeping a long-term compensation policy show higher disclosure, and board compliance is more effective in increasing firm transparency when a policy of long-term incentives are enacted.

Table 8 columns 7, 8 and 9 , the dependent variable is "downside risk" and the coefficient estimated for long-term incentives in model 7 is significantly negative, denoting that "downside risk" is lower in firms with longer-term incentives policies. Robustness checks in columns 8 and 9 confirm results obtained in model 7 . Firms that have instituted a long-term compensation policy have lower downside risk, and board compliance is more effective in reducing the firm downside risk when a policy of long-term

Board". Taken in 14/01/19 from: https://www.conferenceboard.org/retrievefile.cfm?filename $=91317--$ Materials---

Hanley.pdf\&type $=$ subsite 
incentives is in force. In addition, in model 9 only the interaction "board compliance*long-term" shows effectiveness in decreasing downside risk, indicating that board compliance has significant influence on firm risk reduction if a policy of long-term incentives is adopted. All the above results provide support to corroborate Hypothesis $3 b$.

Thus, we make a strong case of long-term incentives for executives impacting long-term sustainability of a firm, and promote long-term shareholder value, aligning with the results of Mohamed and Salazar, (2016).

Table 11

Earnings Smoothing, Stock Price Synchronicity, Downside Risk and Long-Term Incentives

\begin{tabular}{|c|c|c|c|}
\hline \multicolumn{4}{|c|}{ Panel data estimation } \\
\hline \multicolumn{4}{|c|}{ Independent Variable } \\
\hline & \multicolumn{3}{|c|}{ Earnings Smoothing } \\
\hline Variable & 1 & 2 & 3 \\
\hline Long Term Incentives & $\begin{array}{c}0.007 * * \\
(0.003)\end{array}$ & & \\
\hline Board compliance*Short Term & & & $\begin{array}{c}0.059 * * * \\
(0.014)\end{array}$ \\
\hline Long term persistence & & $\begin{array}{c}0.049 * * * \\
(0.025)\end{array}$ & \\
\hline Board compliance*Long Term & & & $\begin{array}{c}0.093 * * * \\
(0.017)\end{array}$ \\
\hline Assets & $\begin{array}{c}0.002 \\
(0.001)\end{array}$ & $\begin{array}{c}0.12 \\
(0.298)\end{array}$ & $\begin{array}{l}0.002^{*} \\
(0.001)\end{array}$ \\
\hline Debt & $\begin{array}{c}-0.016^{* * *} * \\
(0.009)\end{array}$ & $\begin{array}{c}-0.22 \\
(0.530)\end{array}$ & $\begin{array}{c}-0.010 * * * \\
(0.003)\end{array}$ \\
\hline \multicolumn{4}{|l|}{ Market Capitalization } \\
\hline Global Competitive Index & $\begin{array}{c}0.07 \text { *** } \\
(0.015)\end{array}$ & $\begin{array}{c}0.158 * * * \\
(0.043)\end{array}$ & $\begin{array}{c}0.09 \\
(0.012)\end{array}$ \\
\hline Constant & $\begin{array}{c}-0.95 * * * \\
(0.085)\end{array}$ & $\begin{array}{c}-1.43 \\
(0.238)\end{array}$ & $\begin{array}{c}-1.07 \\
(0.064)\end{array}$ \\
\hline Year fixed effects & \multicolumn{3}{|c|}{ YES } \\
\hline Country-firm fixed effects & \multicolumn{3}{|c|}{ YES } \\
\hline Wald Chi Squared & 31.77 & 31.97 & 188.53 \\
\hline Observations & 15135 & 3016 & 23284 \\
\hline
\end{tabular}

Table 12

Earnings Smoothing, Stock Price Synchronicity, Downside Risk and Long-Term Incentives

\begin{tabular}{|c|c|c|c|}
\hline \multicolumn{4}{|c|}{ Panel data estimation } \\
\hline \multicolumn{4}{|c|}{ Independent Variable } \\
\hline & \multicolumn{3}{|c|}{ Stock Price Synchronicity } \\
\hline Variable & 4 & 5 & 6 \\
\hline Long Term Incentives & $\begin{array}{c}-0.017 * * * \\
(0.001)\end{array}$ & & \\
\hline Board compliance*Short Term & & & $\begin{array}{c}-0.084 * * * \\
(0.004)\end{array}$ \\
\hline Long term persistence & & $\begin{array}{c}-0.016 * * \\
(0.008)\end{array}$ & \\
\hline Board compliance*Long Term & & & $\begin{array}{c}-0.17 * * * \\
(0.005)\end{array}$ \\
\hline \multicolumn{4}{|l|}{ Assets } \\
\hline \multicolumn{4}{|l|}{ Debt } \\
\hline Market Capitalization & $\begin{array}{c}-0.13 * * * \\
(0.037)\end{array}$ & $\begin{array}{c}-0.016 \\
(0.056)\end{array}$ & $\begin{array}{c}-0.242 * * * \\
(0.033)\end{array}$ \\
\hline Global Competitive Index & $\begin{array}{c}-0.19 * * * \\
(0.004)\end{array}$ & $\begin{array}{c}-0.278 \text { *** } \\
(0.011)\end{array}$ & $\begin{array}{c}-0.121 * * * \\
(0.033)\end{array}$ \\
\hline Constant & $\begin{array}{l}1.25 * * * \\
(0.028)\end{array}$ & $\begin{array}{l}1.71 * * * \\
(0.063)\end{array}$ & $\begin{array}{c}0.844 * * * * \\
(0.019)\end{array}$ \\
\hline Year fixed effects & \multicolumn{3}{|c|}{ YES } \\
\hline Country-firm fixed effects & \multicolumn{3}{|c|}{ YES } \\
\hline Wald Chi Squared & 4151.61 & 1108.11 & 7098.5 \\
\hline Observations & 10651 & 2105 & 16905 \\
\hline
\end{tabular}

Table 13

Earnings Smoothing, Stock Price Synchronicity, Downside Risk and Long-Term incentives

\begin{tabular}{|c|c|c|c|}
\hline \multicolumn{4}{|c|}{ Panel data estimation } \\
\hline \multicolumn{4}{|c|}{ Independent Variable } \\
\hline & \multicolumn{3}{|c|}{ Downside Risk } \\
\hline Variable & 7 & 8 & 9 \\
\hline Long Term Incentives & $\begin{array}{c}-0.074 * * * \\
(0.006)\end{array}$ & & \\
\hline Board compliance*Short Term & & & $\begin{array}{l}0.054 * \\
(0.028) \\
\end{array}$ \\
\hline Long term persistence & & $\begin{array}{c}-0.117 \text { *** } \\
(0.048)\end{array}$ & \\
\hline Board compliance*Long Term & & & $\begin{array}{c}-0.31 * * * \\
(0.034) \\
\end{array}$ \\
\hline \multicolumn{4}{|l|}{ Assets } \\
\hline \multicolumn{4}{|l|}{ Debt } \\
\hline Market Capitalization & $\begin{array}{c}-5.65 * * * \\
(0.248)\end{array}$ & $\begin{array}{c}-3.57 * * * \\
(0.412)\end{array}$ & $\begin{array}{c}-5.92 * * * \\
(0.023)\end{array}$ \\
\hline Global Competitive Index & $\begin{array}{c}-0.34 * * * \\
(0.031)\end{array}$ & $\begin{array}{c}-0.188 * * * \\
(0.082)\end{array}$ & $\begin{array}{c}-0.211 * * * \\
(0.023)\end{array}$ \\
\hline Constant & $\begin{array}{c}4.50 * * * \\
(0.180)\end{array}$ & $\begin{array}{c}3.031 * * * \\
(0.451)\end{array}$ & $\begin{array}{c}3.214 * * * \\
(0.129)\end{array}$ \\
\hline Year fixed effects & \multicolumn{3}{|c|}{ YES } \\
\hline Country-firm fixed effects & \multicolumn{3}{|c|}{ YES } \\
\hline Wald Chi Squared & 2117 & 361.29 & 4380.63 \\
\hline Observations & 15244 & 3003 & 23505 \\
\hline
\end{tabular}

\section{Conclusions, Limitations and Further Research}

The results of this study emphasize on a number of implications including, but not limited to, decision-making, public policies, organizational strategy and firm performance measures. As mentioned by Tim Leech (2017), stakeholders expect the board of directors to perform their duties with compliance to laws and regulations such as Sarbanes-Oxley, Dodd Frank, Foreign Corrupt Practices, Anti-money Laundering and SEC standards. As evidenced in our research, the boards with long-term orientation, audit committee and higher board independence are more likely to reduce earnings management, improve performance disclosure, abide by compliance policies and thus, increase overall transparency. If the public policy related to corporate governance were to take into account these factors, then, simply by inclusion of some the long-term orientation policies, good corporate governance can be created.

It also advances and substantiates O'Hanley's (2017) and Leech's (2017) argument about relationship between long-term plans and long-term value creation and the policies for the board of directors. Our conclusions indicate that long-term orientation policies interact with good corporate governance and decreasing the likelihood of corrupt practices reducing risk. A board with long-term orientation will have planned strategy for at least 3-5 years (as defined by 'long-term'), improving firm's long-term sustainability.

The need to show short-term results make easy for the board to lose focus on the long term-plan to meet the shortterm goals and this a reason why most firms fail to implement long-term performance policies, but boards need to curb the short-termism by keeping the management focused on long-term health of the companies. The board leadership needs to have "sufficient conviction, influence, and resilience to stand firm in the face of short-term 
pressures" and moreover must have "independent" board leadership to counter short term pressures. Most companies either lack or fail to maintain the required board leadership and goal alignment to accomplish the long-term vision. This could be true especially in the case of public companies which are prone to succumb to fact that "share price need to go up"

A stream of past literature talks about the importance of board compliance and the importance of independent directors with enough experience to ensure satisfactory monitoring of investments by managers and reduce the information advantages that managers have over outside investors. We advance in this field, after addressing endogeneity issues that are corrected with our empirical tests, we find that independent directors with the experience required to adequately oversee and influence a board increase the quality of financial reporting and improve a firm's information environment have incentives to maintain and enhance their reputation as effective monitors (Fama \& Jensen 1983). The supervisory role of independent directors and systems of corporate governance oriented to assure compliance can effectively inhibit firms from issuing distorted financial and performance information.

Additionally, taking into account research requirements about other moderating variables existing between board characteristics and firm transparency and disclosure, we find that boards with a high level of compliance, an audit committee, higher independence and expertise are more likely to adopt executives' long-term incentives policies. Our results after correcting endogeneity issues, demonstrate that good boards are prone to implement long-term incentive policies, this could have impact to control managers' tendency to sacrifice long-term shareholder value for short-term profits (Graham et al., 2005). Our results confirm theoretical work and recent evidence regarding boards that successfully accomplish their fiduciary responsibility, increase their long-term orientation (Porter, 1992; Monks \& Minow, 1995; Barton et al., 2017) and that this long-term orientation interact with board compliance in increasing disclosure and reducing risk.

Our findings confirm that long-term orientation not only discourages opacity but also reduces risk showed by firms in our sample. The long long-term orientation adopted by boards could incentive policies to mitigate the occurrence of extreme losses. Cella et al. (2013) mention that long-term investors reduce negative systematic shocks to the stock prices of firms that they own. Shareholders could be benefit through risk effects caused by long-term decision-making policy supported by the boards. These results are especially important for developing countries as it provides insight on the variables leading to better disclosure and transparency which is usually very low in these countries (Naser et al., 2006; Tsamenyi et al., 2007).
As with any study, there are always limitations. In the case of this research, we don't test for whether equity or shares owned in terms of executive compensation or by the board members affected our hypothesis. In terms of research scope, emerging markets are an arena where governance issues, orientation and board performance have grown in importance, yet only eight emerging markets were included in the study. Also, we don't explore the implication of board size in our conclusions.

We can't provide assurance if the boards of the firms in our sample determine the long-term firm orientation. In principle, board of directors should be the main entity to have power/authority to change financial, operational, investing firm policy. However, it is possible that powerful CEOs can exert significant influence in corporate decisions (Combs et al., 2007). Similarly, external parties such as long-term shareholders (Zhang \& Gimeno 2016) and financial analysts (Yu 2008) can also play an important role in corporate policies and board governance. Our findings show evidence that higher board compliance is related with greater firm-long term orientation and these last two conditions are associated to lower downside risk and better disclosure. Our outcomes could encourage future research that address what is the specific influence of CEO's, longterm shareholders and external financial analysts in this framework and go deeper to find causality relations.

Another issue for future research could be to investigate what extent external factors such as economy, political environment, and market trends affect the hypotheses presented in this study as well as other factors that should be considered, especially ones related to executive compensation, risk and transparency.

In sum, we find support that Boards with (a) an audit committee, (b) higher independence, (c) expertise, (d) and compliance are more likely are more likely to adopt executives' long-term incentives policies and thereby, reduce earnings management and increase the performance disclosure. Additionally, firms with long term incentives orientation are more likely to reduce earnings management, increase the performance disclosure and reduce downside risk.

Our results not only put to rest the arguments that there is no impact of long-term orientation and long-term incentives but also strengthens the stream of literature that supports these variables' impact on earnings management, stock price synchronicity and downside risk. With the international setting of the paper, we have substantiated the external validity of the results across geographies and country-wide regulations. In terms of the public sector companies, these hypotheses may be extended for a different dataset that represents such public companies and results can further be analyzed.

\section{References}

Aldamen, H., Duncan, K., Kelly, S., McNamara, R., \& Nagel, S. (2012). Audit Committee characteristics and firm performance during the global financial crisis. Accounting and Finance, 52, 971-1000. https://doi.org/10.1111/ j.1467-629X.2011.00447.x 
Alhaji, I. A., \& Wan Yusoff, W. F. (2012). An empirical study of the roles of audit committee in promoting good corporate governance. International Conference on Business and Economic Research (3rd ICBER 2012), 12-13 March 2012., Bandung, Indonesia.

Ang, A., Chen, J., \& Xing, Y. (2006). Downside Risk. Review of Financial Studies, 19,1191-1239. https://doi.org/10.1093/rfs/hhj035

Armstrong, C., Core, J., \& Guay, W. (2014). Do independent directors cause improvements in firm transparency? Journal of Financial Economics, 113, 383-403. https://doi.org/10.1016/j.jfineco.2014.05.009

Barka, B. H., \& Legendre, F. (2016). Effect of the board of directors and the audit committee on firm performance: a panel data analysis. Springer Science+Business Media New York 2016. J Manag Gov 2017, 21, $737-755$. https://doi.org/10.1007/s10997-016-9356-2

Barton, D., Manyika, J., \& Williamson, S. K. (2017). Finally, Evidence That Managing for the Long Term Pays Off. Harvard Business Review, February 07, 2017. Taken on line from https://hbr.org/2017/02/finally-proof-thatmanaging-for-the-long-term-pays-off1

Bhattacharya, U., Daouk, H., \& Welker, M. (2003). The world price of earnings opacity. Accounting Review 78, $641-678$. https://doi.org/10.2308/accr.2003.78.3.641

Bower, J. L., \& Lynn, S. P. (2017). Managing for the long-term. Harvard Business Review, 1-19.

Buck, T., Bruce, A., Main, B. G. M., \& Udueni, H. (2003). Long term incentive plans, executive pay and UK company performance. Journal of Management Studies 40, 0022-2380. https://doi.org/10.1111/1467-6486.00397

Cella, C., Ellul, A., \& Giannetti, M. (2013). Investors' horizons and the amplification of market shocks. Review of Financial Studies 26, 1607-1648. https://doi.org/10.1093/rfs/hht023

Chen, J., Hong, H., \& Stein, J. (2001). Forecasting crashes: trading volume, past returns, and conditional skewness in stock prices. Journal of Financial Economics, 61, 345-381. https://doi.org/10.1016/S0304-405X(01)00066-6

Chen, X., Cheng, Q., \& Wang, X. (2015). Does increased board independence reduce earnings management? Evidence from recent regulatory reforms. Review of Accounting Studies 20, 899-933. https://doi.org/10.1007/s11142-0159316-0

Combs, J., Ketchen Jr., D., Perryman, A., \& Donahue, M. (2007). The moderating effect of CEO power on the board composition-firm performance relationship. Journal of Management Studies, 44, 1299-1323. https://doi.org/10.1111/ j.1467-6486.2007.00708.x

Cunningham, L. A. (2008). Rediscovering Board Expertise: Legal implications of the empirical literature. George Washington University Law School. GWU Law School Public Law Research Paper No.363; GWU Legal Studies Research Paper No. 363. https://doi.org/10.2139/ssrn.1024261

Daum, J. H., \& Speed, E. (2015). Building a board for the long term. SpencerStuart. Taken online from https://www.spencerstuart.com/research-and-insight/building-a-board-for-the-long-term.

DeNicolo, G., Laeven, L., \& Ueda, K. (2008). Corporate governance quality: Trends and real effects. Journal of Financial Intermediation 17, 198-228. https://doi.org/10.1016/j.jfi.2007.10.002

Duchin, R., Matsusaka, J., \& Ozbas, O. (2010). When are outside directors effective?. Journal of Financial Economics 96, 195-214. https://doi.org/10.1016/j.jfineco.2009.12.004

Fama, E. F., \& Jensen, M. C. (1983). Agency Problems and Residual Claims. Journal of Law and Economics 26, 327349. https://doi.org/10.1086/467038

Ferguson, B. (2009). Focusing on the Long-term Performance in the Face of Short-term Pressures. Institute of Corporate Directors. Director Journal. 2.

Fuzi, S. F. S, Halim, S. A. A., \& M. K. J. (2016). Board independence and firm performance. Procedia Economics and Finance 37, 460-465. https://doi.org/10.1016/S2212-5671(16)30152-6

Graham, J., Harvey, C., \& Rajgopal, S. (2005). The economic implications of corporate financial reporting. Journal of Accounting and Economics 40, 3-73. https://doi.org/10.1016/j.jacceco.2005.01.002

Hermalin, B. E., \& Weisbach, M. S. (2003). Boards of directors as an endogenously- determined institution: A survey of the economic literature. Economic Policy Review 9, 7-26.

Hermalin, B. E., \& Weisbach, M. S. (1998). Endogenously Chosen Boards of Directors and Their Monitoring of the CEO, The American Economic Review, 88, 96-118.

Huang, W., Liu, Q., Rhee, G., \& Wu, F. (2012). Extreme downside risk and expected stock returns. Journal of Banking \& Finance, 36, 1492-1502. https://doi.org/10.1016/j.jbankfin.2011.12.014

Hutton, A. P., Marcus, A. J., \& Tehranian, H. (2009). Opaque financial reports, R2, and crash risk. Journal of Financial Economics 94, 67-86. https://doi.org/10.1016/j.jfineco.2008.10.003 
Hernan Herrera-Echeverri, Jerry Haar, Daniel Velasquez-Gaviria, Siddharth Upadhyay. Board Long-Term Orientation, ...

Jeanjean, T., Stolowy. (2009). Determinants of board members' financial expertise -Empirical evidence from France. The International Journal of Accounting 44, 378-402. https://doi.org/10.1016/j.intacc.2009.09.002

Jiambalvo, J., Rajgopal, S., \& Venkatachalam, M. (2002). Institutional ownership and the extent to which stock prices reflectfuture earnings. Contemporary Accounting Research, 19, 117-145. https://doi.org/10.1506/EQUA-NVJ9E712-UKBJ

Jin, L., \& Myers, S. (2006). R2 around the world: new theory and new tests. Journal of Financial Economics, 79, 257259. https://doi.org/10.1016/j.jfineco.2004.11.003

Johl Kaur, S., Kaur, S., \& Cooper, B. J. (2015). Board characteristics and firm performance: Evidence from Malaysian public listed firms. Journal of Economics, Business and Management, 3(2). https://doi.org/10.7763/ JOEBM.2015.V3.187

Kallamu, B. S., \& Saat, N. A. M. (2015). Audit committee attributes and firm performance: evidence from Malaysian finance companies. Asian Review of Accounting, 23(3), 206-231. https://doi.org/10.1108/ARA-11-2013-0076

Karamanou, I., \& Vafeas, N. (2005). The Association between corporate boards, audit committees and management earnings forecasts: An empirical analysis. Journal of Accounting Research, 43 (3). https://doi.org/10.1111/j.1475679X.2005.00177.x

Klein, A. (2002). Audit committee, board of director characteristics, and earnings management. Journal of Accounting and Economics, 33, 375-400. https://doi.org/10.1016/S0165-4101(02)00059-9

Leech, T. (2017). Board Oversight of Long-Term Value Creation and Preservation. Harvard Law School Forum on Corporate Governance and Financial Regulation, 2-6.

Leuz, C., Nanda, D., \& Wysocki, P. (2003). Earnings management and investor protection: an international comparison. Journal of Financial Economics 69, 505-527. https://doi.org/10.1016/S0304-405X(03)00121-1

Lopez-Iturriaga, F., Garcia-Meca, E., \& Tejerina-Gaite, F. (2014). Institutional directors and board compensation: Spanish evidence. BRQ Business Research Quarterly (2015) 18, 161-173. https://doi.org/10.1016/j.brq.2014.07.003

Love, I. (2011). Corporate governance and performance around the world: what we know and what we don't, World Bank Research observer 26, 42-70. https://doi.org/10.1093/wbro/lkp030

Monks, R., \& Minow, N. (1995). Corporate Governance (Blackwell, Cambridge, Massachusetts).

Morck, R., Yeung, B., \& Yu, W. (2000). The information content of stock markets: why do emerging markets have synchronous price movements? Journal of Financial Economics 58, 215-260. https://doi.org/10.1016/S0304405X(00)00071-4

Murphy, K. J. (1998). Executive Compensation. Marshall School of Business, University of Southern California. Available at SSRN: https://ssrn.com/abstract=163914. https://doi.org/10.2139/ssrn.163914

Naser, K., Al-Hussaini, A., Al-Kwari, D., \& Nuseibeh, R. (2006). Determinants of corporate social disclosure in developing countries: the case of Qatar. Advances in international accounting, 19, 1-23. https://doi.org/10.1016/ S0897-3660(06)19001-7

O'Hanley, R. P. (2017). Long-Term Value Begins at the Board. Harvard Law School Forum on Corporate Governance and Financial Regulation.

Park, Y., \& Shin, H. (2004). Board composition and earnings management in Canada. Journal of Corporate Finance, 10, 431-457. https://doi.org/10.1016/S0929-1199(03)00025-7

Porter, M. E. (1992). Capital Choices: Changing the Way America Invests in Industry (Council on Competitiveness/Harvard Business School, Boston). https://doi.org/10.1111/j.1745-6622.1992.tb00485.x

Qinghua, W., Pingxin, W., \& Junming, Y. (2007). Audit committee, board characteristics and quality of financial reporting: An empirical research on Chinese securities market. Front. Bus. Res. China, 1(3), 385-400. https://doi.org/10.1007/s11782-007-0023-y

Rashid, A. (2018). Board independence and firm performance: Evidence from Bangladesh. Future Business Journal 4, 34-49. https://doi.org/10.1016/j.fbj.2017.11.003

Salazar, A., \& Mohamed, M. (2016). The duty of corporate directors to tie executive compensation to the long-term sustainability of the firm. Osgoode Legal Studies Research Paper Series. 141. Available at http://digitalcommons.osgoode.yorku.ca/olsrps/141. https://doi.org/10.2139/ssrn.2701455

Sarpal S. (2017). Analyzing performance implications of selected audit committee characteristics: A study of Indian corporate sector. Business Perspectives and Research, 5(2), 137-150. https://doi.org/10.1177/2278533717692915

Shah, A., \& Sunder, S. (1999). Directors' incentives and corporate performance. Carnegie Mellon University.

Tsamenyi, M., Enninful-Adu, E., \& Onumah, J. (2007). Disclosure and corporate governance in developing countries: Evidence from Ghana. Managerial Auditing Journal. https://doi.org/10.1108/02686900710733170 
Willis, A. (2009). Long-term Performance Briefing: Questions for directors to ask. Chartered Professional Accountants of Canada, 4-5.

Xie, B., Davidson III, W., \& DaDalt, P. (2003). Earnings management and corporate governance: The role of the board and the audit committee. Journal of Corporate Finance 9, 295-316. https://doi.org/10.1016/S0929-1199(02)00006-8

Xu, N., Li, X., Yuan, Q., \& Chan, K. C. (2014). Excess perks and stock price crash risk: evidence from China, Journal of Corporate Finance 25, 419-434. https://doi.org/10.1016/j.jcorpfin.2014.01.006

Yermo, J. (2008). Governance and Investment of Public Pension Reserve Funds in Selected OECD Countries. OECD Working Paper No. 15. Available at SSRN: https://ssrn.com/abstract=1116396 or http://dx.doi.org/10.2139/ ssrn.1116396

Yu, F. (2008). Analyst coverage and earnings management. Journal of Financial Economics 88, $245-271$. https://doi.org/10.1016/j.jfineco.2007.05.008

Yuan, R., Sun, J., \& Cao, F. (2016). Directors' and officers' liability insurance and stock price crash risk, Journal of Corporate Finance 37, 173-192. https://doi.org/10.1016/j.jcorpfin.2015.12.015

Zhang, Y., \& Gimeno, J. (2016). Earnings pressure and long-term corporate governance: Can long- term-oriented investors and managers reduce the quarterly earnings obsession? Organization Science 27, 354-372. https://doi.org/10.1287/ orsc.2016.1056

Zhou, H., Owusu-Ansah, S., \& Maggina, A. (2018). Board of Directors, Audit Committee, and Firm Performance: Evidence from Greece. Journal of the Chinese Institute of Chemical Engineers https://doi.org/10.1016/ j.intaccaudtax.2018.03beas.002

The article has been reviewed.

Received in September 2019; accepted in October 2020.

This article is an Open Access article distributed under the terms and conditions of the Creative Commons Attribution 4.0 (CC BY 4.0) License (http://creativecommons.org/licenses/by/4.0/). 